九州大学学術情報リポジトリ

Kyushu University Institutional Repository

The Potential Analysis of Food Waste Management using Bioconversion of The Organic Waste by The Black Soldier Fly (Hermetia illucens) Larvae in The Cafeteria of The Faculty of Engineering, Universitas Indonesia

Ibadur rohman, Kayy is

Graduate School of Environmental Engineering, University of Indonesia

Gusniani, Irma

Faculty of Environmental Engineering, University of Indonesia

Hartono, M Djoko

Faculty of Environmental Engineering, University of Indonesia

Suwar tha, Nyoman

Faculty of Environmental Engineering, University of Indonesia

https://doi.org/10.5109/2740946

出版情報 : Evergreen. 7 (1)，pp.61-66，2020-03. 九州大学グリーンテクノロジー研究教育センター バージョン :

権利関係 : 


\title{
The Potential Analysis of Food Waste Management using Bioconversion of The Organic Waste by The Black Soldier Fly (Hermetia illucens) Larvae in The Cafeteria of The Faculty of Engineering, Universitas Indonesia
}

\author{
Kayyis Ibadurrohman ${ }^{1 *}$, Irma Gusniani ${ }^{2 *}$, Djoko $\mathrm{M} \mathrm{Hartono}^{2}$, Nyoman Suwartha ${ }^{2}$ \\ ${ }^{1}$ Graduate School of Environmental Engineering, University of Indonesia, Indonesia \\ ${ }^{2}$ Faculty of Environmental Engineering, University of Indonesia, Indonesia \\ *Author to whom correspondence should be addressed: \\ E-mail: kayyis.ibadurrohman@alumni.ui.ac.id, irma@eng.ui.ac.id
}

(Received October 31, 2019; Revised December 16, 2019; accepted February 24, 2020).

\begin{abstract}
Abstract. The majority of waste made in Indonesia fall into the organic category which amounts to 58\%. The Cafeteria of The Faculty of Engineering, Universitas Indonesia (FT UI) is one of the highest contributors of organic waste. The food waste management that was done is only limited to composting, which takes around 6-7 weeks. One of the alternatives that could be used for food waste management is bioconversion which uses the larvae of black soldier fly (Hermetia illucens). The purpose of this study are: to obtain the knowledge regarding the amount of FT UI Cafeteria's organic waste generation, analyze the ideal duration of the bioconversion, and analyze the bioconversion potential from organic waste. The bioconversion container that is used is a rectangular-shaped 9.6 L plastic container with the size of $32 \times 25 \times 12 \mathrm{~cm}$. This container was chosen based on the assumption that every container will be filled with $1 \mathrm{~kg}$ of substrate with its height no higher than $5 \mathrm{~cm}$ or the highest amount of substrate. The height of the substrate was obtained by comparing the container volume with the waste density that will be used as the substrate. The first step of this study was done in the laboratory scale which uses 4 variations of the bioconversion duration which are 7, 14, 21, and 28 days. The ideal bioconversion duration that was obtained from the second phase of the study which aims to obtain empirical evidence regarding the waste management potential in the existing scale. The results showed that there is an average of $46.27 \mathrm{~kg}$ of waste generation per day which consists of $87 \%$ or $40.45 \mathrm{~kg}$ of low-cellulose organic waste which can be used as a bioconversion substrate with a density of $0.94 \mathrm{~kg} / \mathrm{L}$. From 4 variation of the duration bioconversion, the ideal duration are 12 days. As for the existing waste management potential, the bioconversion could reduce the waste as much as $75 \%$ with a WRI of $6.25 \%$ per day and also could produce the larva biomass of about 800 grams per $4 \mathrm{~kg}$ of waste. Another parameters, the ECD rate is $26.67 \%$, the RGR is $8.29 \%$ per day and the RSR rate is $82.23 \%$. Moreover, after the bioconversion, the larvae contain $29.1 \%$ protein and $11.86 \%$ fat.
\end{abstract}

Keywords: Bioconversion, Organic waste, Black soldier fly, Hermetia Illucens, Food waste

\section{Introduction}

The majority of waste that was made in Indonesia are food waste or organic waste which amounts to the $58 \%$ of the total waste, or around 22.4 million tons per year ${ }^{14)}$. Organic or food waste could cause many problems, because organic waste decompose easily which then causes various issues, such as ground and water pollution, and spreading many diseases through flies, to name a $\mathrm{few}^{3), 25) 23)}$. The Cafeteria of The Faculty of Engineering, Universitas Indonesia (FT UI) are one of the highest contributors of food waste, which is around $32.1 \mathrm{~kg} /$ day or $72.8 \%$ of the total organic waste production ${ }^{1)}$. Currently, the food waste management used composting which takes a long time (6-7 weeks) and needed a large space ${ }^{4), 18)}$.

One of the food waste management alternatives that could be used is the bioconversion using the larvae of Black Soldier Flies (Hermetia illucens) which is a method of food waste management which uses insect's larvae to absorb the nutrition from waste and converts it into the larvae's biomass ${ }^{9), 10)}$. Several benefits of using black soldier fly larvae for bioconversion are waste reduction up to $55 \%$ and also produce larvae biomass, which contains high protein, around $45-50 \%$ and it is suitable for the food of livestock such as fish and poultry ${ }^{11), 12)}$. In addition, the bioconversion residue that was made could be used as 
compost for plants ${ }^{9)}$. The bioconversion process also only takes around 2-3 weeks and doesn't need additional technology or substances because the process happens naturally ${ }^{7}$.

\section{Literature Review}

Waste refers to any leftovers that came from human, animals, or plants which usually are solid and are thrown away, unusable, and unwanted ${ }^{25)}$. Based on the type, food waste is defined as organic waste which came from food leftovers and kitchen, restaurant, or other waste ${ }^{15)}$. As for waste generation, it refers to the amount of waste produced in a certain place, with certain activities in a certain period of time ${ }^{25)}$. The waste production data have units in $\mathrm{kg} /$ person/day, $\mathrm{kg} /$ day, $\mathrm{L} /$ person/day, or L/day which could be obtain through direct measurement in the field based on the waste sampling method in accordance with SNI 19-3964-1994 regarding The Method of Taking and Measuring Examples of Urban Waste Generation and Composition $^{24)}$.

The process of bioconversion using the larvae of black soldier flies are effective because the larvae are gluttonous in nature and have a strong mouth, this in turns makes the organic waste decomposing process faster ${ }^{20)}$. Moreover, the larvae have longer life cycle than other fly species such as Musca domestica and Lucilla sericata, this made the bioconversion process more effective ${ }^{6}$.

In the bioconversion process, the larvae depend on the environmental conditions such as humidity, food amount and quality, temperature, and the oxygen level, these conditions are necessary to monitor so that the bioconversion process could done to its full potential ${ }^{7}$. One of the factor that needs to be watched is the temperature. The ideal temperature for the livelihood of the larvae is $36^{\circ} \mathrm{C}$, if the temperature is too low or reached below $25^{\circ} \mathrm{C}$, the growth larvae will be hampered, and the highest temperature that the larvae could live in is $45^{\circ} \mathrm{C}$, if the temperature exceeds that the larvae will die because the environment is too hot ${ }^{13)}$. Other factor that needs to be watched is the water level, if it's too high or too low it will hamper the larvae growth or causes it to die. The ideal substrate water level for the larvae growth in the bioconversion process is $60-80 \%$. If the level is too high, then it is necessary to conduct pretreatment process to reduce the water level which uses the gravitation method or using a press tool ${ }^{5), 8)}$. Lastly, the factor that needs to be watched is the quality of the larvae's food nutrition ${ }^{9), 19), 21) . ~}$ Low food nutrition quality such as cow feces will make the larvae grow slower and smaller than the high quality ones such as food waste ${ }^{16), 17)}$.

\section{Study Method}

Feedstock that are used for the bioconversion came from the waste in FT UI's Cafeteria. Waste sampling was done using the modified version of SNI 19-3964-1994 Regarding The Method of Taking and Measuring
Examples of Urban Waste Generation and Composition ${ }^{24)}$. The type of waste measured in this study is the organic waste of the food leftovers that have been sorted out. Waste sampling was done in the cafeteria for six days straight following the working hours of the cafeteria. The measurement that was done in those six days was aimed to obtain the fluctuation rate and the average of waste production in a week.

The bioconversion phase starts with the process of hatching the eggs for 3-4 days in hatchery which is a plastic container that contains chicken food for the newly hatched larvae mixed with water which consists of $70 \%$ water and $30 \%$ chicken food ${ }^{2), 26)}$. After the eggs hatched, the larval maintenance was conducted inside the hatchery cage until the larvae was five days old. The bioconversion container that is used is a rectangular-shaped $9.6 \mathrm{~L}$ plastic container with the size of $32 \times 25 \times 12 \mathrm{~cm}$. This container was chosen based on the assumption that every container will be filled with $1 \mathrm{~kg}$ of substrate with its height no higher than $5 \mathrm{~cm}$ or the highest amount of substrate ${ }^{8)}$. The height of the substrate was obtained by comparing the container volume with the waste density that will be used as the substrate. The bioconversion container was then placed inside a cage made out of steel frames with the size of $200 \times 50 \times 70 \mathrm{~cm}$. The right, left, and back side of the cage was coated with fiber plastic, and for the upper side was covered using plywood, and the front and lower side used a $1 \mathrm{~mm}^{2}$ ram wire which serves to prevent natural predators, rainwater, and sunlight from coming in but still has good air circulation. In each of the foot of the bioconversion cage, a bucket that contains soap water was placed to prevent ants and other small insects from coming in.

Before the organic waste was used as the bioconversion feedstock, a pretreatment was conducted to condition the organic waste to better the larvae growth ${ }^{7}$. The pretreatment includes sorting and dewatering process. The sorting process was done to separate the organic waste that contains high and low cellulose. The high-cellulose waste, which can't be used as a bioconversion substrate, includes eggshells, banana leaf, seeds, and so on. As for the high cellulose ones, which can be used as a bioconversion substrate, includes rice leftovers, meat, and vegetables. The dewatering process used a $60 \mathrm{~L}$ sealed bucket that has a height of $52 \mathrm{~cm}$ and $45 \mathrm{~cm}$ diameter. Placed inside the bucket is a divider made from a $15 \mathrm{~cm}$ PVC which is to create an empty space for the leachate at the base of the bucket. Above the divider, a 1 x $1 \mathrm{~m}$ calico cloth was placed as a filter, calico was used because of its durability and has a big enough pores to filter the leachate water. After the filter was placed, the waste can be put inside the bucket and then was sealed for 48 hours $^{8)}$.

The bioconversion process was divided into two phases. Phase one was done to find the ideal bioconversion duration. In this phase there are 4 variants with the experiment was conducted in the laboratory scale. As for phase two, it was done to obtain the bioconversion 
potential which will use the ideal duration that was obtained in the first phase and was conducted in the existing scale.

The results from phase two will be used as the base of analysis to design the bioconversion facility in The Faculty of Engineering, Universitas Indonesia.

In phase one, the ratio of substrate and the amount of larvae that was used in the bioconversion process was based on the study conducted by The Eawag-Swiss Federal Institute of Aquatic Science and Technology ${ }^{8}$, which is around 670 larvae for every one kilogram of organic waste. Four variations was used for the bioconversion duration, first variation is the bioconversion process for 7 days, second variation is 14 days, third variation is 21 days, and fourth variation is 28 days. These variations were used to see the effect of the duration towards the effectiveness of the bioconversion process and its effect towards the larvae that was produced. To obtain an accurate representation of the data, for every variation, three replications with the same sample source was conducted.

After phase one was completed, phase two begins. Phase two experiment was done using the ideal duration that was obtained from phase one. In this phase, the feedstock source, container, cage, and the larvae ratio are the same as the ones in phase one, but the amount of waste that was used as feedstock was optimized in each of the bioconversion container. Based on the calculation, every container could hold about 4 kilograms of feedstock or substrate with the height of the substrate inside the container is $5 \mathrm{~cm}$. The summary of bioconversion specification for every phase can see in Table 1.

Table 1. Bioconversion Specifications (Laboratory Scale and

\begin{tabular}{|l|l|l|l|l|l|}
\hline Phase & $\begin{array}{c}\text { Substr } \\
\text { at (kg) }\end{array}$ & $\begin{array}{c}\text { Larva } \\
\mathbf{e} \\
\text { (pcs) }\end{array}$ & $\begin{array}{c}\text { Duratio } \\
\mathbf{n} \\
\text { (days) }\end{array}$ & $\begin{array}{c}\text { Contain } \\
\text { er (L) }\end{array}$ & $\begin{array}{c}\text { Height } \\
\text { of The } \\
\text { Substra } \\
\text { te (cm) }\end{array}$ \\
\hline $\begin{array}{l}\text { One } \\
\text { (Laborato } \\
\text { ry Scale) }\end{array}$ & 1 & 670 & $\begin{array}{l}4 \\
\text { variatio } \\
\text { ns } \\
(7,14,21 \\
\text { and 28) }\end{array}$ & 9,6 & $<5$ \\
\hline $\begin{array}{l}\text { Two } \\
\text { Existing } \\
\text { Scale) }\end{array}$ & 4 & 2680 & $\begin{array}{l}\text { Optimal } \\
\text { duration } \\
\text { from } \\
\text { phase } \\
\text { one }\end{array}$ & 9,6 & 5 \\
\hline
\end{tabular}

After the bioconversion process was done next is the larvae and residue will be harvested by pouring the larvae and residue above a $1 \mathrm{~cm}$ filter, then the filter will be sifted so that the larvae and the residue will be separated. The separated larvae then will be washed with clean water and rinsed with hot water to kill the larvae. Lastly, the larvae will be dried and kept for later use for calculating and studied upon ${ }^{7)}$.
To calculate the bioconversion process efficiency, the Waste Reduction Index (WRI), Efficiency of Conversion of Digested-feed (ECD), Relative Growth Rate (RGR), and Relative Survival Rate (RSR) parameters was used. WRI is a calculation method that was used to calculate the amount of waste reduction during the bioconversion process $^{7)}$. ECD is for the efficiency rate of the conversion process. RGR is for the larvae growth rate from the initial bioconversion process until the last one. Lastly, the RSR indicates the survival rate of the larvae in a single colony or group during the bioconversion process ${ }^{22), 27)}$. The equations from the parameters that were used can be seen in the following equations:

$$
\begin{aligned}
& D=\frac{W-R}{W} \\
& W R I=\frac{D}{t} \times 100 \\
& E C D=\frac{B}{(I-F)} \times 100 \\
& R G R=\frac{(W 2-W 1)}{W 2 \times t} \times 100 \\
& R S R=\frac{W 2}{W 1} \times 100(5)
\end{aligned}
$$

Eq. 1 and Eq. 2, W is sum of organic waste (g), $\mathrm{R}$ is waste residue $(\mathrm{g}), \mathrm{t}$ is bioconversion time (days), $\mathrm{D}$ is overall reduction parameter, and WRI is Waste Reduction Index (\% per day). Eq. 3, B is larvae biomass ( $\mathrm{g}$ ), I is sum of food given $(\mathrm{g}), \mathrm{F}$ is sum of residue $(\mathrm{g})$, and ECD is Efficiency of Conversion of Digested-Feed (\%). Eq. 4 and Eq. 5, W1 is initial larvae mass (g), W2 is final larvae mass $(\mathrm{g}), \mathrm{t}$ is bioconversion time $(\mathrm{t})$, RGR is Relative Growth Rate (\% per day), and RSR is Relative Survival Rate (\%).

In addition to measuring the efficiency of the bioconversion process, a measurement of the larvae biomass was also conducted to see its suitability as feedstock. The parameter that was tested in the biomass measurement includes protein, and fat.

\section{Result and Discussion}

The results showed that the average of organic waste from food leftovers of the FT UI Cafeteria is $46.27 \mathrm{~kg} /$ day (fig. 1). The results of waste composition measurement showed that $87 \%$ from the total organic waste is lowcellulose waste which can be used as bioconversion feedstock. Based on the measurement, it is shown that the average of organic waste density of food leftover in the cafeteria is $0.94 \mathrm{~kg} / \mathrm{L}$. The results of the organic waste measurement and the phase one bioconversion can be seen in the following graphs: 


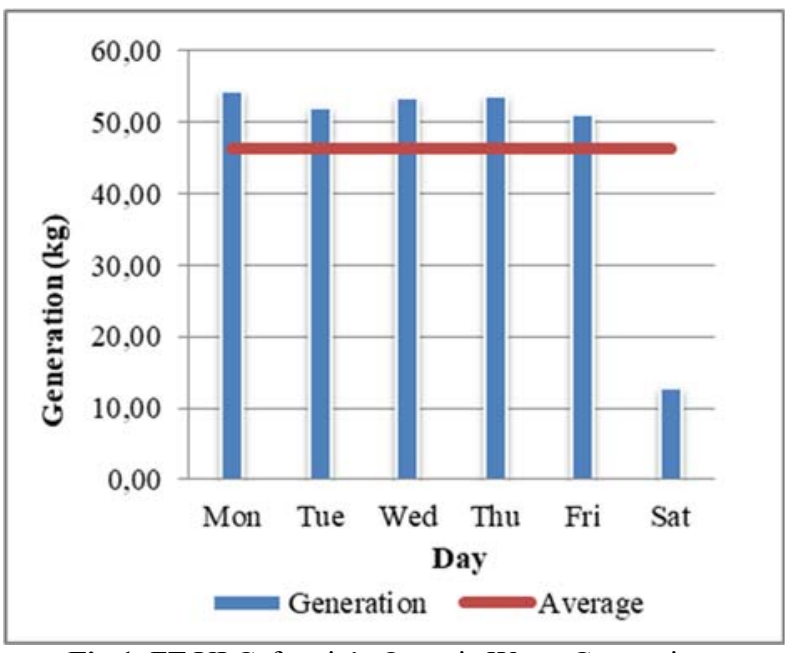

Fig 1. FT UI Cafeteria's Organic Waste Generation Fluctuation

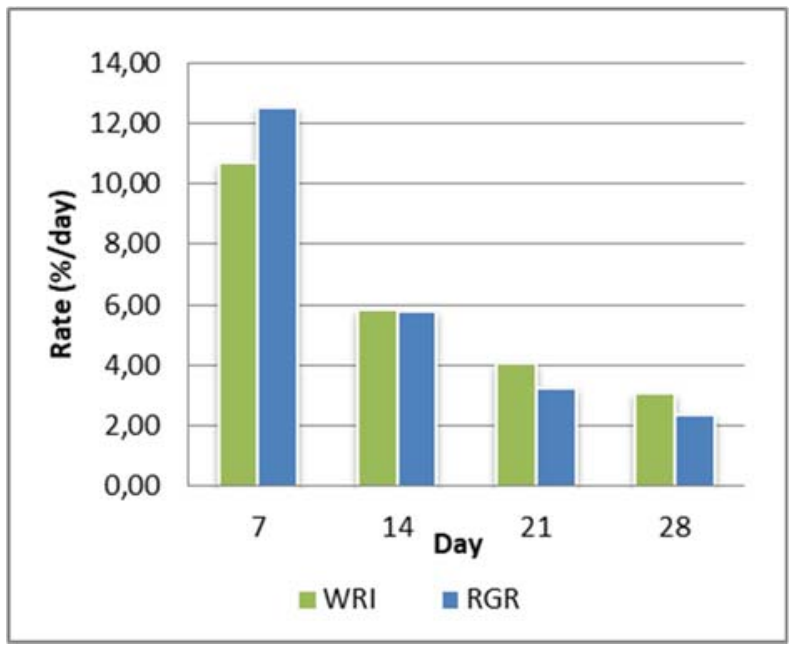

Fig 2. The WRI and RGR Rate

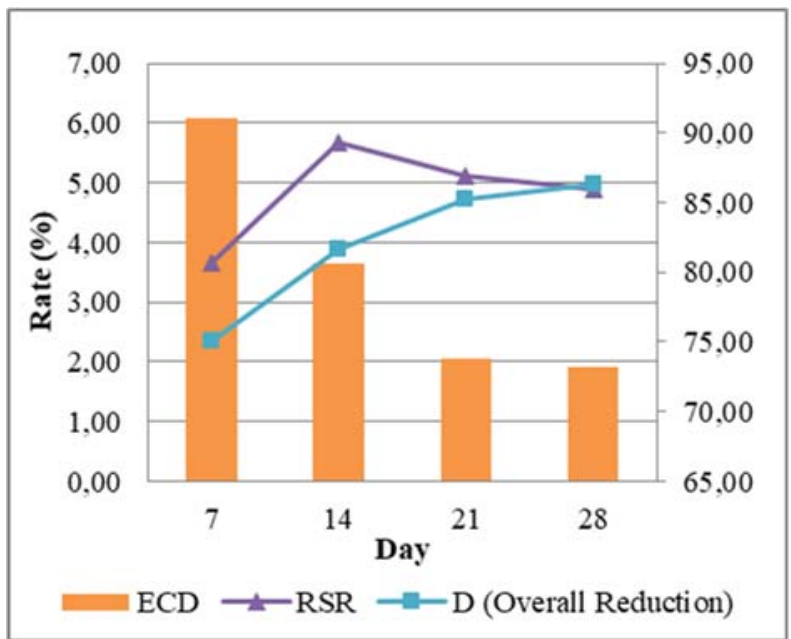

Fig3. The ECD, RSR, and D Rate

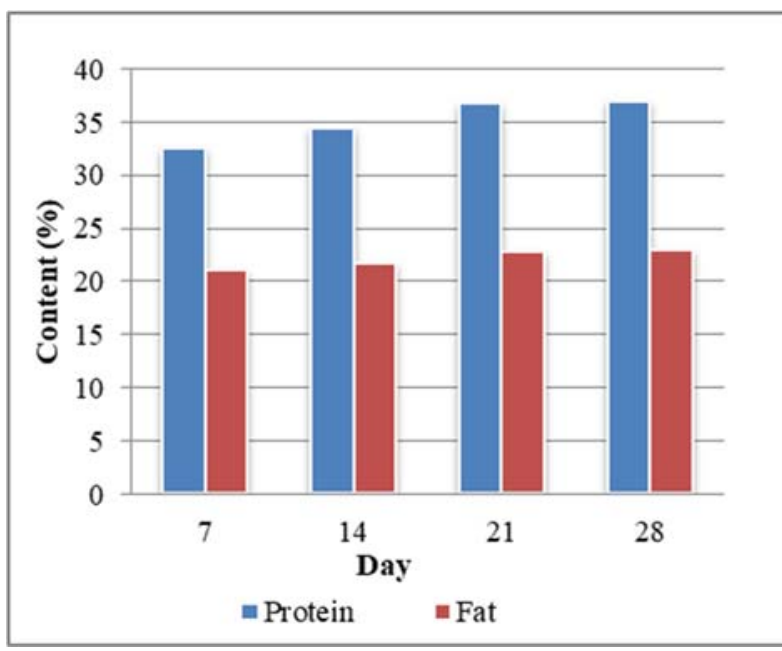

Fig 4. The Effects of The Bioconversion Duration towards the Larvae's Protein and Fat Level

The results showed that the WRI, ECD, and RGR rate are the highest in the 7 days variant and the rate decreases in the 14, 21, and 28 variants (fig. 2, 3). The higher rate indicates that the bioconversion process is best in the 7day variant. However, the variant has the lowest RSR rate. This is because in the larvae harvesting stage using the filter, a lot of larvae didn't separate properly and instead got mixed with the residue because its size is too small and thus, not homogenous. This small and different sizes was because the bioconversion process is too short so the larvae haven't reach its full size yet. Meanwhile, the 14day variant has the highest RSR rate (fig. 3) because the larvae have reached their full size and more homogenized so that the harvesting process can be done more optimal. As for the 21 and 28-day variant, the RSR rate decreases again, this is caused by the decreasing substrate condition, the condition becoming drier, and also the decreasing substrate nutrition made the larvae growth became hampered and death. Based on the characteristics of the bioconversion product, the protein and fat inside the larvae have the lowest rate in the 7-day variant and kept increasing until the 28-day variant (fig. 4).

Based on the previous statements, it can be concluded that the WRI, ECD, and RGR rate are the highest in the 7day variant, but the highest RSR rate was in the 14-day variant. As for the larva protein and larva rate in the 7 and 14-day variant were the lowest two out of the 4 variants, but the difference of the rates between these variants are not significant. It can be concluded that the ideal bioconversion duration is in the range of 7 to 14 days despite the protein and fat rate in this range are not the highest of the four variants. The chosen ideal range is in line with previous studies that showed that the ideal time for the bioconversion process using the black soldier fly larvae is around 10-12 days ${ }^{8}$. The decision of the ideal duration was also based on the working days of the cafeteria as a source of bioconversion feedstock. The cafeteria operates for six days a week, so in the span of two weeks there will be 12 times waste will come to the planned bioconversion facility. To ease the bioconversion 
operational cycle, an adequate bioconversion duration was chosen in regards to the working days of the cafeteria for 2 weeks which are 12 days. Based on the results and analysis using the available literatures, it is decided that the ideal duration for bioconversion in the planned facility is 12 days.

The results from the phase two of the bioconversion showed promising results. It is shown that from the $4 \mathrm{~kg}$ of waste that was processed, around $0.8 \mathrm{~kg}$ of larvae and $1 \mathrm{~kg}$ of residue was produced. Based on the efficiency, it's shown that during the 12-day bioconversion process, the waste was reduced by $75 \%$ or around $3 \mathrm{~kg}$. The $6.25 \%$ rate of the WRI indicates that there is a $250 \mathrm{~g} /$ day waste reduction during the 12-day process. The $26.67 \%$ ECD indicates that about $1066.8 \mathrm{~g}$ of substrate was converted into the larvae biomass. For the $8.24 \%$ /day rate of RGR indicates that there is an increase in larvae mass around $0.03 \mathrm{~g} /$ larvae/day during the 12-day process. And for the $82.23 \%$ rate of RSR indicates that from the initial 2680 larvae, around 2204 larvae successfully survived and grown. Lastly, after the bioconversion process, the larvae have $29.1 \%$ protein and $11.86 \%$ fat.

\section{Conclusion}

Based on the results, it can be concluded that, the average of the FT UI Cafeteria organic waste generation is $46.27 \mathrm{~kg}$ which consists of $87 \%$ or $40.45 \mathrm{~kg}$ of lowcellulose organic waste which can be used as a bioconversion substrate with a density of $0.94 \mathrm{~kg} / \mathrm{L}$. Based on the WRI, ECD, RSR, and RGR rate from the bioconversion phase one, and considering the organic waste production and operational days of the FT UI Cafeteria, it can be concluded that the ideal duration of the bioconversion using the black soldier fly larvae is 12 days. From the phase two experiments, it can be concluded that the 12-day organic waste bioconversion process could reduce the waste as much as $75 \%$. From its efficiency, the WRI rate is $6.25 \%$ per day, the ECD rate is $26.67 \%$, the RGR is $8.29 \%$ per day and the RSR rate is $82.23 \%$. Moreover, after the bioconversion, the larvae contain $29.1 \%$ protein and $11.86 \%$ fat.

\section{Acknowledgements}

The authors would like to thank Universitas Indonesia for sponsoring this research under the PITTA 2017 project funding scheme under The Assignment Agreement Letter from the Directorate of Research and Community Service Universitas Indonesia

Number 2418/UN2.R3./HKP.05.00/2018.

\section{References}

1) Banaget, C. K, "Pengaruh Parameter Fisik - Kimia Terhadap Aktivitas Mikroorganisme selama Proses Pengomposan Sampah Kantin Fakultas Teknik UI
(Studi Kasus: Sampah Kantin Fakultas Teknik UI)," B.E Thesis, University of Indonesia, Indonesia, (2014).

2) Booth, D. C., \& Sheppard, C, "Oviposition of the black soldier fly, Hermetia illucens (Diptera: Stratiomyidae): eggs, masses, timing, and site characteristics," Environmental entomology, 13 (2), 421-423 (1984).

3) Buchner, B., Fischler, C., Gustafson, E., Reilly, J., Riccardi, G., Ricordi, C., \& Veronesi, U, "Food waste: causes, impacts and proposals," Barilla Center for food and Nutrition (2012).

4) Cahaya, T. S and Nugroho A, "Pembuatan Kompos dengan Menggunakan Limbah Padat Organik (Sampah Sayuran dan Ampas Tebu)," B.E Thesis Diponegoro University, Indonesia (2009).

5) Cheng, J. Y., Chiu, S. L., \& Lo, I. M, "Effects of moisture content of food waste on residue separation, larval growth and larval survival in black soldier fly bioconversion," Waste Management (2017).

6) Cickova, H., Newton, G. L., Lacy, R. C., \& Kozanek, $\mathrm{M}$, "The use of fly larvae for organic waste treatment," Waste Management, 35, 68-80 (2014).

7) Diener, S., Zurbrügg, C., Gutiérrez, F. R., Nguyen, D. H., Morel, A., Koottatep, T., \& Tockner, K, "Black soldier fly larvae for organic waste treatmentprospects and constraints," Proceedings of the WasteSafe, pp. 13-15 (2011).

8) Eawag-Swiss Federal Institute of Aquatic Science and Technology, "Black Soldier Fly Biowaste Processing” Switzerland: Author, (2017).

9) Fahmi, M. R, "Optimalisasi proses biokonversi dengan menggunakan mini-larva Hermetia illucens untuk memenuhi kebutuhan pakan ikan," Pros Sem Nas Masy Biodiv Indon, Depok, Indonesia, Vol 1 ISSN, 2407-8050, pp. 139-144 (2015).

10) Furman, D.P., Young, R.D., Catts, E.P, "Hermetia Illucens (Linnaeus) as a Factor in the Natural Control of Musca domestica Linnaeus," Journal of Economic Entomology, 52, 917-921 (1959).

11) Hahn, D. A, "Larval nutrition affects lipid storage and growth, but not protein or carbohydrate storage in newly eclosed adults of the grasshopper Schistocerca americana" Journal of Insect Physiology, 51(11), 1210-1219 (2005).

12) Hale, O.M, "Dried Hermetia illucens larvae (Diptera: Stratiomyidae) as a feed for poultry," Journal of the Gorgia Entomological Society, 8, 16-20 (1973).

13) Hartoto, A. N, "Budidaya Maggot Lalat Hitam (Hermetia Illucens) pada Limbah Sayuran Sebagai Bahan Pakan Ikan dengan Menggunakan Pot Biokonversi," Bachelor final project, Gajah Mada University, Indonesia (2011).

14) Kementerian Negara Lingkungan Hidup, "Statistik Persampahan Domestik Indonesia 2008" Jakarta (2008)

15) Kiran, E. U., Trzcinski, A. P., Ng, W. J., \& Liu, Y, "Bioconversion of food waste to energy: a review," 
Fuel, pp. 134, 389-399 (2014).

16) Manurung, R., Supriatna, A., Esyanthi, R. R., \& Putra, R. E, "Bioconversion of rice straw waste by black soldier fly larvae (Hermetia illucens L.): optimal feed rate for biomass production," J Entomol Zool Stud, 4, 1036-1041 (2016).

17) Myers, H.M., Tomberlin, J.K, Lambert, B.D., Kattes, D, "Development of black soldier fly (Diptera: Stratiomydiae) larvae fed dairy manure," Environmental Entomology, pp. 37, 11-15 (2008).

18) Mu'minin, A, "Desain operasi penanganan sampah kampus Universitas Indonesia Depok," B.E Thesis, University of Indonesia, Indonesia (2013).

19) Newton L, Sheppard C, Watson DW, Burtle G, Dove $\mathrm{R}$, "Using the black soldier fly, Hemertia Illucens, as a value-added tool for the management of swine manure," Animal and Poultry Waste Management Center, North Carolina State University, Raleigh, NC, 17 (2005).

20) Oliveira, F., Doelle, K., List, R., \& O'Reilly, J. R, "Assessment of Diptera: Stratiomyidae, genus Hermetia illucens (L., 1758) using electron microscopy," J Entomol. Zool. Stud, pp. 3(5), 147152 (2015).

21) Rachmawati, R., Buchori, D., Hidayat, P., Hem, S., \& Fahmi, M. R, "Perkembangan dan kandungan nutrisi larva Hermetia illucens (Linnaeus) (Diptera: Stratiomyidae) pada bungkil Kelapa Sawit," Indonesia Entomology Journal, pp. 7(1), 28 (2010).

22) Scriber, J. M., \& Slansky Jr, F, "The nutritional ecology of immature insects," Annual review of entomology, 26(1), 183-211 (1981).

23) Santisak, K. "Attitude toward BioremediationRelated Technology and Relation with Company Social Responsibility" Evergreen Joint Journal of Novel Carbon Resources Sciences \& Green Asia Strategy Vol. 6, Issue 03, pp 240-245, September (2019)

24) Standar Nasional Indonesia 19-3694-1994, "Metode Pengambilan dan Pengukuran Contoh Timbulan Sampah Perkotaan," Badan Standar Nasional (1994)

25) Tchobanoglous, G., Theisen, H., \& Vigil, S, "Integrated Solid Waste Management," Mcgraw-Hill, Singapore, (1993).

26) Tomberlin, J. K., \& Sheppard, D. C, "Factors influencing mating and oviposition of black soldier flies (Diptera: Stratiomyidae) in a colony," Journal of Entomological Science, 37(4), 345-352 (2002).

27) Waldbauer, G. P, "The consumption and utilization of food by insects. In Advances in insect physiology," Academic Press, Vol. 5, pp. 229-288 (1968). 